\title{
Restoration of the tree-nesting Peregrine Falcon (Falco peregrinus) population in the Volga-Ural Region
}

\author{
Alexey Pazhenkov ${ }^{1 *}$, Igor Karyakin ${ }^{2}$, Denis Afanasyev ${ }^{1}$, \\ Alexandra Krivopalova ${ }^{3} \&$ Elena PazhenKova ${ }^{4}$
}

Received: December 03, 2018 -Revised: December 11, 2018 -Accepted: December 21, 2018

This is a contribution submitted to the Proceedings of the World Conference on the Peregrine Falcon in Budapest in September 2017.

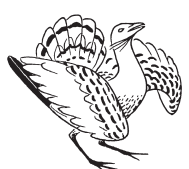

Pazhenkov, A., Karyakin, I., Afanasyev, D., Krivopalova, A. \& Pazhenkova, E. 2018. To restoration of the tree-nesting Peregrine Falcon (Falco peregrinus) population in the Volga-Ural Region. - Ornis Hungarica 26(2): 254-258. DOI: 10.1515/orhu-2018-0033 of the cliff-nesting Peregrine Falcon. In June 2016 and 2017, in the Southern Ural Mountains and Bugulma-Belebey Upland, we discovered four nests of Peregrine Falcons, which were threatened by destruction due to various anthropogenic and biological factors. For preventing the death of the broods, the chicks were transferred from the occupied nesting niches in the rock cliffs to nesting platforms. On nesting platforms they spent from 3 to 12 days where they were fed by adults regularly. All four broods ( 9 young) flew out successfully and demonstrated typical behavior for the Peregrines of their age. Adults fed fledglings and taught them to hunt.

Keywords: Peregrine recolonization, Volga-Ural Region, nesting types, imprinting on tree-nesting

Összefoglalás A vándorsólymok fészkelési szokásai is változhatnak. Vizsgálatunkban sziklákon fészkelö párok viselkedését figyeltük meg fára helyezett fészkekbe átköltöztetett fiókáik nevelésével kapcsolatban. 2016 és 2017 júniusában négy pusztulással fenyegetett fészket találtunk a dél-uráli Bugulma-Belebey felföldön, amelyek emberi zavarásnak és más biotikus tényezőknek voltak kitéve. A fészekaljak megmentése érdekében a fiókákat az eredeti fészekrakó helyről mesterségesen létrehozott költőhelyekre szállítottuk át. A fiókák ezeken a mentőhelyeken 3-12 nap időtartamot töltöttek és a felnőttek rendszeresen etették őket. Mind a négy fészekalj, összesen 9 fióka sikeresen kirepült, és a koruknak megfelelő viselkedést mutatta. A felnőtt egyedek tovább etették, miközben vadászni is tanították őket.

Kulcsszavak: sólyom áttelepítés, Volga-Ural Régió, fészektípus, fészekhely-bevésődés

\footnotetext{
${ }^{1}$ Laboratory of Conservation Biology “Ecoton”,e-mail:flynx@mail.ru

2SibecocenterLLC., / RRRCN, e-mail: ikar research@mail.ru

${ }^{3}$ Samara State University, e-mail: alexyks95@gmail.com

${ }^{4}$ St. Petersburg State University, e-mail: pazhenkova.e@gmail.com

* corresponding author
} 


\section{Introduction}

The habitat restoration and abundance of Peregrine Falcons is uneven for populations with the different nesting strategies in Europe during the $20^{\text {th }}$ century after "pesticide" eco-catastrophe. As it is known, the population of the cliff-nesting Peregrine Falcon has demonstrated a considerably successful increase due to using of the ledge rocks and compound relief forms as nesting sites. At the same time, the Peregrine Falcons do not inhabit the vast plains of forest and stepper-forest zones from Western Europe to the Ural Mountains. Several dozens of breeding pairs of tree-nesting Peregrine Falcons were known in West and Central Europe, which were formed as a result of successful projects of Peregrine Falcon reintroduction in Germany, Poland and elsewhere in the EU (Langgemach et al. 1997, Kirmse 2001, Wegner et al. 2005, Mizera \& Sielicki 2009, Cade 2013).

Since the end of the 20th century, the number of the cliff-nesting Peregrine Falcons in the mountains of the Southern Ural has been increasing, and nowadays, breeding pairs are distributing to the piedmont of the Ural Mountains and along the Volga River (Karyakin 1998, Karyakin \& Pazhenkov 2009).

However, the cliff biotopes here are limited and subject to significant anthropogenic influence, and thus, nesting stereotype does not allow the Peregrine Falcon to occupy vast plains with rich trophic base. For these reasons, we carried out some field work for imprinting the tree-nesting stereotype among the cliff-nesting Peregrine Falcons in the Ural Mountains.

The successful imprinting of the tree-nesting stereotype in chicks of Peregrine Falcons was applied in Germany and Poland. The chicks from Peregrine Falcon hatcheries were transferred to the special cage on tall pine trees at the age of 30 days. The young Peregrine Falcons were fed (1-day chicks of quail) in the cages until 4-6 weeks after the Peregrine Falcon first flight. Thus, the young falcons have been formed tree-nesting stereotype. This approach demonstrated impressive results of the recolonization in the historic tree-nesting populations in Europe. Though, one of the most serious problems with artificial breeding of tree-nesting Peregrine Falcons (the hacking method) is the lack of parents who teach young birds to hunt and acquire social skills (Kleinstäuber et al. 2009, Sielicki \& Sielicki 2010).

We have offered to apply somewhat different method of a forming tree-nesting behavior pattern at the wild chicks of the cliff-nesting Peregrine Falcon in the Volga-Ural Region in 2002. Recent observations have shown, that forming of the tree-nesting stereotype at cliff-nesting Peregrine Falcon chicks is possible in the case of the broods transferring at the age of 25-30 days from cliff nesting sites on the artificial nesting platforms in the trees. Besides, along with imprinting of the tree-nesting stereotype, chicks will be given parental care, hunting experience and all the rest natural social skills. Subsequent observations have shown a constant growth of number of the population of the cliff Peregrine Falcon in the Ural Mountains and possibility to use it as a donor for forming of the tree-nesting population. As we have seen, adults of the Peregrine Falcons demonstrate numerous cases of the care for the brood as well as the chicks bringing up despite of strong disturbance and human presence within nesting sites, and also bringing up of the chicks left their nests prematurely.

By the first step, it is necessary to confirm experimentally parental care of chicks while transferring them from the nesting niche on the tree platform. 


\section{Method}

We have tested the technique of a forming tree-nesting behavior pattern in the chicks of the cliff-nesting Peregrine Falcon (Falco peregrinus).

In June 2016 and 2017, in the Southern Ural Mountains and Bugulma-Belebey Upland, we discovered four nests of Peregrine Falcons, which were threatened by destruction due to various anthropogenic and biological factors. For preventing the death of the broods, the chicks were transferred from the occupied nesting niches in the rock cliffs to nesting platforms. These circumstances contributed to the decision to conduct the experiment.

Nesting platforms for simulating nests of large birds of prey (Buteo buteo, Accipiter gentilis, Aquila chrysaetos) were built in the upper third of the tree crown near the trunk. Nest platforms were arranged in such a way the trunk and crown of the tree would provide shading of the platform part and protection from the wind and rain. For these purposes, an additional canopy of branches was also created.

During the construction we took into account the need for a free approach to the nest platform, as well as a panoramic view of the adjacent valley.

We moved a small amount of food residues, feathers and stones, polluted with excrement, from the nest niches to attract adult Peregrine Falcons to nest platforms.

Near all the nested platforms were equipped with trail cameras. Chicks on the platforms were observed with telescopes. We did not visit platforms after the chicks were transferred. To avoid disturbance on the platforms No. 1-3, the trail cameras were installed at a distance of about 5-7 $\mathrm{m}$ from nesting platforms, for which some of the feedings were not recorded due to incorrect operation of trail cameras, while we were observing the adult Peregrine Falcons with prey with a telescope.

On nesting platform No. 4 the trail camera was installed 4 days after the chicks were transferred, as there was technically impossible to install trail camera for a distance of more than 1.5-2 m. Too close installation of the trail camera at the nest was considered to be an additional factor of disturbance that could slow the first arrival of the adult Peregrine Falcons. The first four days we recorded individual arrivals of the adults on the nest platform using a telescope.

Thus, we not able to spot some feedings and visits of the nesting platforms by adults and young birds.

\section{Experiment}

Nesting platform No. 1 was constructed on linden (Tilia cordata) at a height of $5 \mathrm{~m}$ from the ground. The tree was located at a distance of $17 \mathrm{~m}$ from the nesting niche. The cliff niche and the nesting tree were situated in the upper third of the steep forested slope with a total height difference about $150 \mathrm{~m}$.

The brood consisted of three 33-39 days old chicks. The eldest chick could fly and left the nesting niche at the moment of carrying (15 June 2016). During the observation period he stayed close to the nesting niche and flew from one roost site to another. 
The chicks spent three days on the nesting platform No. 1. During this period, the feeding was noted at least two times. On the third day, the chicks flew to the cliffs at a distance of $15 \mathrm{~m}$ from the nesting platform.

Nesting platform No. 2 was built on elm (Ulmus glabra) at a height of $4 \mathrm{~m}$ from the ground. The tree was located at a distance of $15 \mathrm{~m}$ from the cliff nesting niche. The cliff niche and the nesting tree were situated in the upper third of the steep forested slope with a total height difference about $50 \mathrm{~m}$.

The brood consisted of two 28-30 days old chicks, which were transferred on the nesting platform on 16 June 2016. The chicks spent 11 days on the nesting platform, after that they started to fly to the nearest cliffs, located $5 \mathrm{~m}$ away from the nest. However, they were observed to return to the platform during the subsequent 8 days, where they were fed by adult bird. The adult fed the chicks at least 8 times in the period of their staying on the platform.

Nesting platform No. 3 was constructed on oak (Quercus robur) at a height of $7 \mathrm{~m}$ from the ground. The tree was located at a distance of $25 \mathrm{~m}$ from the cliff nesting niche. The cliff niche and the nesting tree were located in the upper third of the steep forested slope with a total height difference about $170 \mathrm{~m}$.

The brood consisted of two 28-32 days old chicks, which were transferred on the nesting platform on 18 June 2016. The chicks spent on the nesting platform at least 10 days. During this period, the feeding was noted at least 32 times.

Nesting platform No. 4 was constructed on birch (Betula pendula) at a height of $12 \mathrm{~m}$ from the ground. The tree was located on the edge of a flat plateau at a distance of $100 \mathrm{~m}$ from the cliff nesting niche. The cliff niche was located at the top of the steppe slope with a total height difference about $100 \mathrm{~m}$.

The brood consisted of three 26-31 days old chicks, which were transferred on the nesting platform on 19 June 2017. The chicks spent on the nesting platform at least 13 days. During this period, the feeding was noted at least 27 times.

Adult Peregrine Falcons fed chicks on nesting platforms on the day of transfer or the following day.

All four broods (9 young) fledged successfully and demonstrated behavior typical for Peregrine Falcons of their age. Adults fed fledglings and taught them to hunt. As they grow older, joint flights of adults and young Peregrine Falcons were carried out, followed by their return to the nesting site after a few hours of absence.

\section{Summary}

The care of adult Peregrine Falcons about their broods after transferring them on nesting platforms on a tree was justified by the experiment.

We consider the installation of the nesting platforms on trees near inhabited cliff nests and carrying of 26-30 days old chicks on them can become a promising method for reintroduction of the tree-nesting Peregrine Falcon populations in the Volga-Ural Region. At the same time, i strict observation of the methodical receptions directed to the preservation of 
the brood, minimization of disturbance and attracting of the adult Peregrine Falcons to nesting platform is necessary.

Of course, the most important factor that can ensure the success of this technique is the presence of a large cliff-nesting population of a Peregrine Falcon with a steadily growing number.

Moreover, the consequent interactions between cliff and tree-nesting Peregrine Falcon populations, which can have unique specific features in the Volga-Ural Region, will require a peculiar study in the future.

\section{References}

Cade, T. J. 2013. Baumbrütende Wanderfalken in Europa im Vergleich mit den Brutgewohnheiten weltweit gestern und heute // Die Rückkehr des Wanderfalken in die großen Wälder [Tree-nesting Peregrine Falcons in Europe compared to the breeding habits worldwide - yesterday and today // The return of the Peregrine Falcon to the great forests]. - Arbeitskreis Wanderfalkenschutze, Freiberg, Germany, pp. 100-111. (in German)

Karyakin, I. V. 1998. Raptors of the Ural Region. Birds of Prey (Falconiformes), Owls (Strigiformes). - Perm (in Russian)

Karyakin, I. \& Pazhenkov, A. 2009. Population trends of the Peregrine Falcon in the Volga-Ural region (Russia) for twenty years. - In: Sielicki, J. \& Mizera, T. (eds.) Peregrine Falcon Populations - status and perspectives in the $21^{\text {st }}$ century. - Turul - Poznań University of Life Sciences Press, Warsaw-Poznań, pp. 335-356.

Kirmse, W. 2001. Wiedereinbürgerung baumbrütender Wanderfalken (Falco peregrinus) in Mitteleuropa [Repatriation of tree-nesting Peregrine Falcons (Falco peregrinus) in Central Europe]. - Zeitschrift fur Jagdwissenschaft 47(3): 165-177. (in German)

Kleinstäuber, G., Kirmse, W. \& Sömmer, P. 2009. The return of the Peregrine to eastern Germany - recolonisation in the west and east; the formation of an isolated tree-nesting subpopulation and further management. - In: Sielicki, J. \& Mizera, T. (eds.) Peregrine Falcon Populations status and perspectives in the $21^{\text {st }}$ century. - Turul - Poznań University of Life Sciences Press, Warsaw-Poznań, pp. 641-676.

Langgemach, T., Sömmer, P., Kirmse, W., Saar, C. \& Kleinstäuber, G. 1997. Erste Baumbrut des Wanderfalken Falco p. peregrinus in Brandenburg zwanzig Jahre nach dem Aussterben der Baumbrüterpopulation [First brood of Peregrine Falcon Falco p. peregrinus in Brandenburg twenty years after the extinction of the tree-nesting population]. - Vogelwelt 118: 79-94. (in German)

Mizera, T. \& Sielicki, J. 2009. Breeding status of the Peregrine Falcon in Poland during the pre- and post- DDTera. - In: Sielicki, J. \& Mizera, T. (eds.) Peregrine Falcon Populations - status and perspectives in the $21^{\text {st }}$ Century. - Turul - Poznań University of Life Sciences Press, Warsaw-Poznań, pp. 153-168.

Sielicki, S. \& Sielicki, J. 2010. Restytucja sokoła wędrownego Falco peregrinus w Polsce a fundusze Unijne. R. 12. [Restitution of Peregrine Falcon Falco peregrinus in Poland and EU. R. 12.]. - Zeszyt 2 (25): 191-219. (in Polish)

Wegner, P., Kleinstäuber, G., Baum, F. \& Schilling, F. 2005. Long-term investigation of the degree of exposure of German Peregrine Falcons (Falco peregrinus) to damaging chemicals from the environment. - Journal of Ornithology 146(1): 34-54. DOI: 10.1007/s10336-004-0053-6

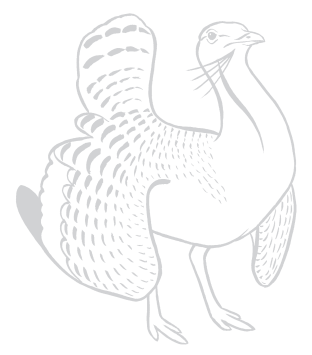

